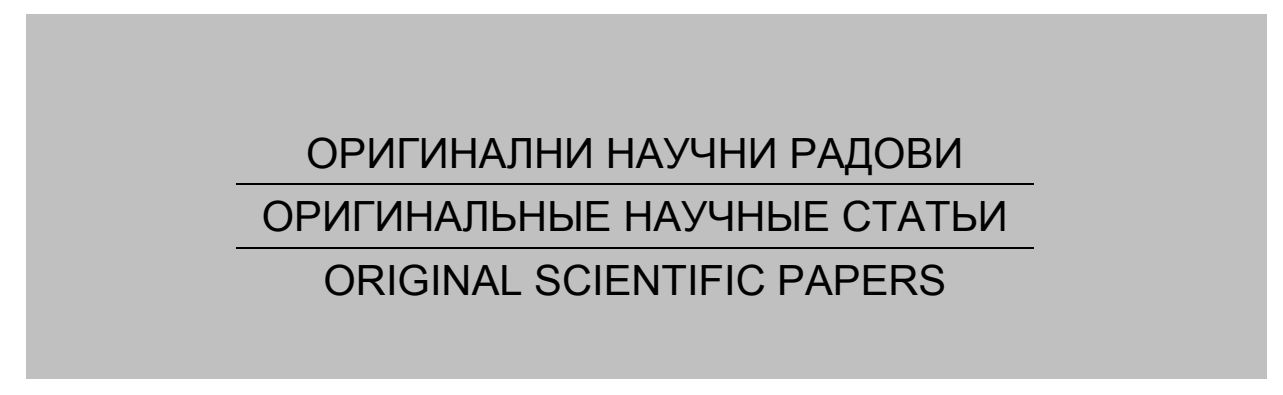

\title{
ENERGETIC ADDITIVES IN EXPLOSIVE CHARGES OF ROCKETS USED DURING THE WAR AGAINST THE FR YUGOSLAVIA IN 1999
}

\author{
Mirjana N. Anđelković-Lukić \\ Military Technical Institute, Belgrade, Republic of Serbia, \\ e-mail: mirjana.andjelkovic.lukic45@gmail.com, \\ ORCID iD: (1)http://orcid.org/0000-0002-5076-4901
}

DOI: 10.5937/vojtehg67-22549; https://doi.org/10.5937/vojtehg67-22549

FIELD: Chemical Technology

ARTICLE TYPE: Original Scientific Paper

ARTICLE LANGUAGE: English

\section{Summary:}

The use of explosive devices containing energy enhancement additives such as halogen compositions, metals in a form of fine powders and waxes resulted in the formation of toxic gases after their detonation. The released harmful gases together with the products of destruction of bombed targets had the effects of special chemical warfare.

Key words: explosive devices, energetic additives, chemical warfare.

\section{Introduction}

Experts in Serbia were mostly focused on understanding the effects of depleted uranium on the health of human population overlooking, however, the danger of chemical pollution caused especially by a fluid pyralene (Anđelković-Lukić, 2015a,2015b) and its burning products. Pyralene was incinerated when high voltage transformers were bombed. One of the most harmful products of pyralene decomposition is dioxin which is one of the most dangerous pollutants of natural environment (Anđelković-Lukić, 2006).

Additional pollution of the environment came from the use of weapons containing explosive charges of different chemical compositions which, when detonated, released poisoning and suffocating gases as well as many other contaminants of ear, water and soil. 

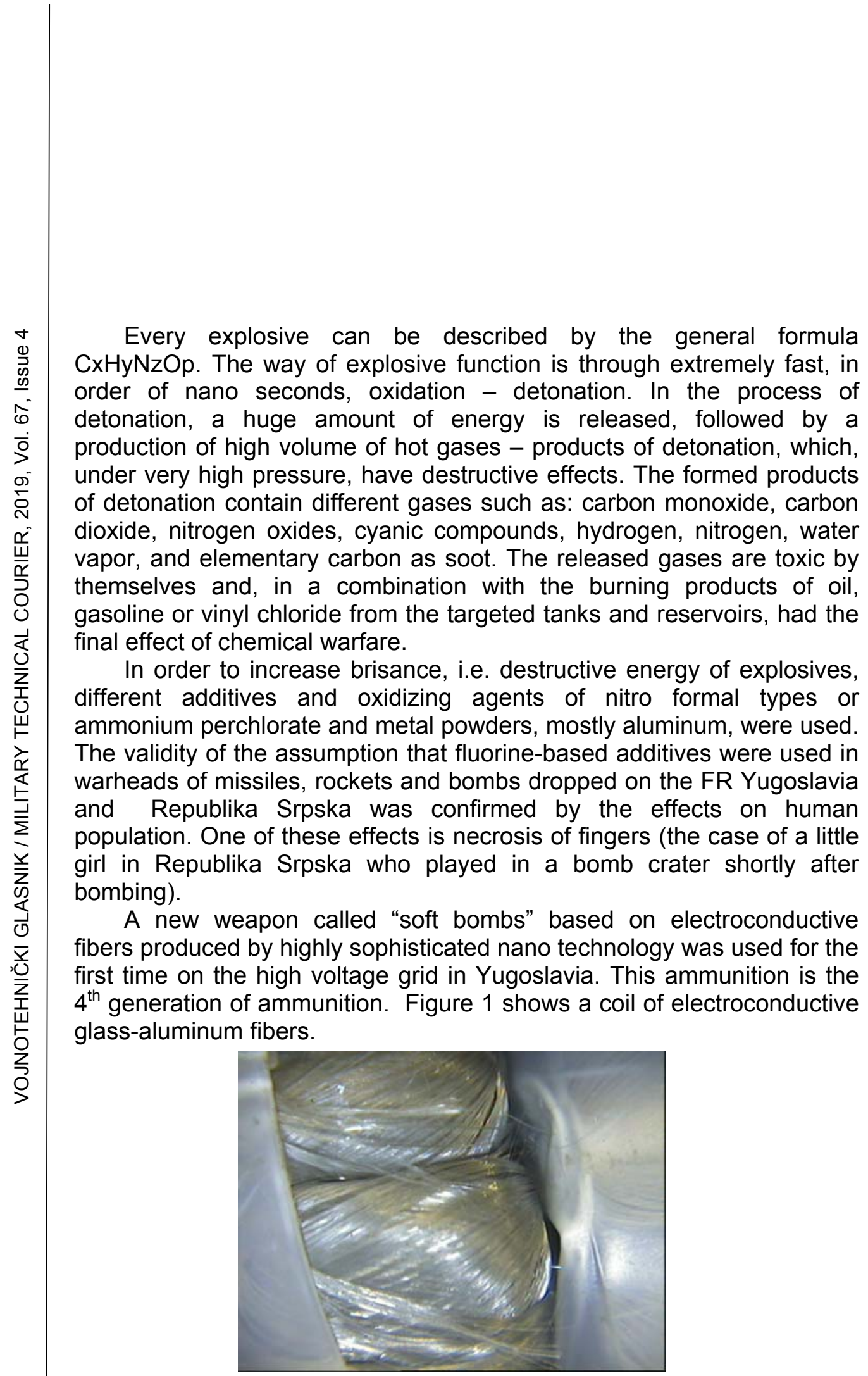

Picture 1 - Coils of electroconductive fibers on a coil

Puc. 1 - Катушки токопроводящей нити

Слика 1 - Намотаји електропроводљивих влакана на калему 
The $3^{\text {rd }}$ generation were "graphite bombs"used in the Iraq bombing and produced also by nano technology. (Anđelković-Lukić, 2015a)

\section{Energetic additives to explosive charges}

Research on the addition of fluorine in forms of formals into nitrocompounds was started in the USA in the late fifties of the last century. In 1961, upon a request from "Aerojet-General-Corporation" based on Navy needs, experiments involving the addition of fluorine into nitro compounds were carried out in the "Office of Naval Research" laboratories, Arlington, Virginia.

The objective of this research was to develop new propellants for long-range missiles. As a result of this research, several fluorine-based nitroformals were synthesized.

These very toxic compounds are also used as additives to explosives and as additives to liquid rocket propellants. In explosive compositions, ammonium perchlorate and aluminum powder are often used as energetic additives. Ammonium perchlorate is a strong oxidizer used as an additive to explosives as well as an additive to gunpowder and solid rocket propellants. In development and research laboratories of NATO countries, especially in the USA and France, there is an ongoing search for new, cheaper and more powerful explosives than "classical" hexogen and octogen. In line with this, a new CL-20 explosive was synthesized in the nineties of the last century.

It was named after the laboratory where it was synthesized for the first time (China Lake in California) (Anđelković-Lukić, 2009). CL-20 is a nitramine-based explosive about $20 \%$ more powerful than octogen $(H M X)$. This is the reason why it has the number 20 in its name (Anđelković-Lukić, 2009). Even though the brisance of this explosive is $20 \%$ higher than that of octogen, additives based on fluorinated nitro formals are used.

These compounds are added to octogen which was phlegmatized with polymer pDNPA, and hexogen is added to a fluorine copolymer. Such compositions and their velocities of detonation (VOD) are shown in Table 1.

There is a realistic assumption that these kinds of compositions were implemented in some ammunition used in the bombing of Yugoslavia. 
Table 1 - Explosive compositions fluorinated containing nitro formals and fluorine polymers (Anđelković-Lukić, 2000), (Dobratz, 1981)

Таблица 1 - Взрывчатые составы с фрторсодержащими нитрофрормами и фоторполимерами(Anđelković-Lukić, 2000), (Dobratz, 1981)

Табела 1 - Експлозивни састави са фрлуорованим нитроформалима и фрлуорним полимерима (Anđelković-Lukić, 2000), (Dobratz, 1981)

\begin{tabular}{|c|c|c|c|c|}
\hline Explosive & Composition & $\%$. & $\begin{array}{l}\text { Density, } \\
\text { (g/cm3) }\end{array}$ & VOD, $(\mathrm{m} / \mathrm{s})$ \\
\hline LX-09-0 & $\begin{array}{l}\text { HMX } \\
\text { pDNPA } \\
\text { FEFO }\end{array}$ & $\begin{array}{r}93.0 \\
4.6 \\
2.4\end{array}$ & 1.837 & 8810 \\
\hline PBX 9010 & $\begin{array}{l}\text { RDX } \\
\text { Kel-F }\end{array}$ & $\begin{array}{l}90 \\
10\end{array}$ & 1.78 & 8370 \\
\hline RX-49-AE & $\begin{array}{l}\text { CL-20 } \\
\text { FEFO } \\
\text { nitroformal mixture }\end{array}$ & $\begin{array}{r}80.46 \\
9.77 \\
9.77\end{array}$ & 1.887 & 8950 \\
\hline
\end{tabular}

pDNPA - Bis(2,2-dinitropropil)acetal

FEFO-bis (2,2,2-fluorodinitroetil)formal

Kel-F- Chlorotrifluoroethylene/vinilidinfluoride copolymer, 3/1

\section{Detonation products of explosives containing fluorine compounds}

Detonation of explosives containing fluorinated nitroformals (Anđelković-Lukić, 2015a,2015b), (Minier \& Behrens, 1997) in their compositions as well as burning of liquid rocket propellants containing these compounds lead to the formation of very toxic detonation products such as hydrogen fluoride, hydrofluoric acid, very reactive fluoric radicals, and fluoric oxides. All these aggressive compounds are formed under adiabatic conditions during detonation. Airborne hydrogen fluoride (g) reacts with traces of water present in the air to form hydrofluoric acid. The concentration of this acid of only $1 \mathrm{~cm}^{3}$ in $1 \mathrm{~m}^{3}$ of air can severely damage the human body and cause heavy poisoning. Hydrofluoric acid is a very strong poison, extremely harmful to the human tissue. Detonation of fluoric compounds may lead to the formation of strong toxic gases of fluoric oxides.

If in a detonation process fluorine is formed, it will react very forcefully with water by capturing hydrogen and releasing huge quantities of atomic oxygen - ozone, hydrogen peroxide, fluoric monoxide, and hydrogen fluoride. 


\section{Decomposition of fluorine- containing explosives}

Detonation or burning of this kind of compounds releases a number of reactive chemical radicals (Minier \& Behrens, 1997). In the equations below, only radicals and molecules of the highest concentration in decomposition products of two explosives of nitro-formal type are presented:

bis(2,2,2-fluorodinitro-ethyl) formal, (FC(NO2)CH2O]2CH2), FEFO

and

bis(2,2,2-fluorodinitro ethyl) difluoroformal ([FC(NO2)2CH2O]2CF2) DFF.

Both explosives are very toxic liquids. Their decomposition gives a big number of fluoro radicals.

1. $\left[\mathrm{FC}\left(\mathrm{NO}_{2}\right) \mathrm{CH}_{2} \mathrm{O}_{2} \mathrm{CH}_{2} \rightarrow \mathrm{HF}+\mathrm{F}^{*}+\mathrm{CF}^{*}+\mathrm{CH}_{2} \mathrm{~F}^{*}+\mathrm{CNF}+\mathrm{C}_{2} \mathrm{H}_{2} \mathrm{~F}^{*}\right.$ $+\mathrm{CHNF}+\mathrm{C}_{2} \mathrm{H}_{2} \mathrm{OF}^{*}+\mathrm{C}_{2} \mathrm{H}_{4} \mathrm{OF}^{*}+\mathrm{C}_{2} \mathrm{H}_{2} \mathrm{NOF}+\mathrm{C}_{3} \mathrm{H}_{5} \mathrm{O}_{2} \mathrm{~F}+\mathrm{C}_{2} \mathrm{H}_{2} \mathrm{~N}_{2} \mathrm{O}_{3} \mathrm{~F}^{*}+$ $\mathrm{C}_{2} \mathrm{H}_{2} \mathrm{~N}_{2} \mathrm{O}_{4} \mathrm{~F}^{*}$

2. $\left[\mathrm{FC}\left(\mathrm{NO}_{2}\right)_{2} \mathrm{CH}_{2} \mathrm{O}_{2} \mathrm{CF}_{2} \rightarrow \mathrm{HF}+\mathrm{F}^{*}+\mathrm{CF}^{*}+\mathrm{CH}_{2} \mathrm{~F}^{*}+\mathrm{CNF}+\mathrm{C}_{2} \mathrm{H}_{2} \mathrm{~F}^{*}\right.$ $+\mathrm{CHNF}+\mathrm{C}_{2} \mathrm{H}_{2} \mathrm{OF}^{*}+\mathrm{C}_{2} \mathrm{H}_{4} \mathrm{OF}^{*}+\mathrm{C}_{2} \mathrm{H}_{2} \mathrm{NOF}+\mathrm{C}_{3} \mathrm{H}_{5} \mathrm{O}_{2} \mathrm{~F}+\mathrm{C}_{2} \mathrm{H}_{2} \mathrm{~N}_{2} \mathrm{O}_{3} \mathrm{~F}^{*}+$ $\mathrm{C}_{2} \mathrm{H}_{2} \mathrm{~N}_{2} \mathrm{O}_{4} \mathrm{~F}^{*}+\mathrm{C}_{5} \mathrm{H}_{5} \mathrm{NO}_{5} \mathrm{~F}_{2}+\mathrm{CHO}_{2} \mathrm{~F}$

FEFO is a liquid explosive with a velocity of detonation of $7500 \mathrm{~m} / \mathrm{s}$ at a density of $1.60 \mathrm{~g} / \mathrm{cm}^{3}$.

DFF is also a liquid explosive, more difficult to initiate and with a velocity of detonation of $6849 \mathrm{~m} / \mathrm{s}$ at a density of $1.67 \mathrm{~g} / \mathrm{cm}^{3}$ (Minier \& Behrens, 1997). Since it has two more atoms in its formula than FEFO, it is more toxic as well.

\section{Detonation products of explosives containing ammonium perchlorate and aluminum}

Very similar reactions with comparable toxicity of reaction products are identified in the decomposition of chlorine-based compounds such as ammonium perchlorate (Cai et al, 2008).

As it can be seen from Table 2, this strong oxidizer is used in high percentage in a number of explosive compositions. 
Table 2 - Compositions of the explosives used (Anđelković-Lukić, 2015a,2015b)

Таблица 2 - Составы используемых взрывчатых веществ (Anđelković-Lukić, 2015a,2015b)

Табела 2 - Састав коришћених експлозива (Anđelković-Lukić, 2015a,2015b)

\begin{tabular}{|l|l|l|l|}
\hline Explosive, $\%$ & Energetic additive, $\%$ & $\begin{array}{l}\text { Aluminum powder, } \\
\%\end{array}$ & Additive, \% \\
\hline $\begin{array}{l}\text { Octogene, HMX } \\
94 \%\end{array}$ & $\begin{array}{l}\text { nitrocellulose } \\
\text { Hexogene, RDX }\end{array}$ & & $\begin{array}{l}\text { CEF}^{*} \\
3 \%\end{array}$ \\
$59 \%$ & & & $\begin{array}{l}\text { Vax } \\
\text { TNT }\end{array}$ \\
$39 \%$ & & & $2.0 \%$ \\
\hline Hexogen & Ammonium & Aluminum & \\
48.0 & perchlorate & $27 \%$ & \\
\hline Hexogen $24 \%$ & $25 \%$ & & \\
Metrioltrinitrate & Ammonium & Aluminum & \\
$21 \%$ & $28 \%$ & $27 \%$ & \\
\hline TNT & & & \\
$80 \%$ & & Aluminum & \\
\hline TNT & Ammonium nitrate & Aluminum & \\
$50 \%$ & $25 \%$ & $25 \%$ & \\
\hline
\end{tabular}

${ }^{*}$ CEF- trihloretil phosphate

In more recent explosive charging formulations, nano-particle aluminum is added to increase energy efficiency and have better characteristics than aluminum in micrometer dimensions. Nano-powders of aluminum, due to a larger surface area, can increase the burning rate of the propellant and as such are more used in propellants than in mixtures with explosives. (Sundaram et al, 2015), (Weidong et al, 2008)

As it can be seen from Table 2, powdered aluminum is added only to explosives that are not phlegmised by polymeric energy materials, since such PBX explosives decrease the rate of detonation (Brousseau \& Anderson, 2002). Explosives with aluminum additives have low sensitivity and good mechanical properties.

Addition of aluminium powder and ammonium perchlorate into explosive charges builds up internal energy and consequently increases the destructive and burning effect of the projectile at the target. Ammonium perchlorate has positive oxygen balance, $34.04 \%$, and by its addition negative oxygen balance of brisant explosives can be modified (Brousseau \& Anderson, 2002). The decomposition of ammonium 
perchlorate via burning (oxidizing process) can be explained by a few models. The most acceptable model is the classical model defining the burning process in a few consecutive steps. Endothermic decomposition of ammonium perchlorate results in the formation of perchloric acid and ammonia according to the reaction:

$$
\mathrm{NH}_{4}{ }^{+} \mathrm{ClO}_{4}{ }^{-} \rightarrow \mathrm{NH}_{3}+\mathrm{HClO}_{4}-58 \mathrm{kcal} / \mathrm{mol}
$$

The formed ammonia and perchloric acid are further exothermically decomposed into the final combustion products: chlorine, hydrogen chloride, nitrogen oxides, and water.

$$
2 \mathrm{NH}_{3}+2 \mathrm{HClO}_{4} \stackrel{\mathrm{O}_{2}}{\rightarrow} \mathrm{Cl}_{2}+2 \mathrm{NO}_{2}+4 \mathrm{H}_{2} \mathrm{O}
$$

The second presumed way of the decomposition of ammonium perchlorate can be described by the equation:

$10 \mathrm{NH}_{4} \mathrm{ClO}_{4} \rightarrow 2,5 \mathrm{Cl}_{2}+2 \mathrm{~N}_{2} \mathrm{O}+2,5 \mathrm{NOCl}+\mathrm{HClO}_{4}+1,5 \mathrm{HCl}+18,75 \mathrm{H}_{2} \mathrm{O}$ $+1,75 \mathrm{~N}_{2}+6,375 \mathrm{O}_{2}$

Under adiabatic conditions of detonation, an extremely toxic, suffocating and aggressive gas - elemental chlorine is formed. Chloric oxides and radicals formed by detonation react with water from the air to form "acidic rain" which destroys and damages vegetation. The most common detonation products of the mixture of explosive CxHyNzOp and ammonium perchlorate $\mathrm{NH} 4 \mathrm{ClO} 4$ are presented in the equation below.

$\mathrm{C}_{\mathrm{x}} \mathrm{H}_{\mathrm{y}} \mathrm{N}_{\mathrm{z}} \mathrm{O}_{\mathrm{p}}+\mathrm{NH}_{4} \mathrm{ClO}_{4} \rightarrow \mathrm{Cl}_{2}+\mathrm{HCl}+\mathrm{Cl}^{*}+\mathrm{ClO}_{2}^{*} \mathrm{CCl}^{*}+\mathrm{CH}_{2} \mathrm{Cl}^{*}+\mathrm{CNCl}+$ $\mathrm{C}_{2} \mathrm{H}_{2} \mathrm{Cl}^{*}+\mathrm{CHNCl}+\mathrm{C}_{2} \mathrm{H}_{2} \mathrm{OCl}^{*}+\mathrm{C}_{2} \mathrm{H}_{4} \mathrm{OCl}^{*}+\mathrm{ClCH}_{2} \mathrm{CN}^{*}+\mathrm{C}_{2} \mathrm{H}_{2} \mathrm{NOCl}+$ $\mathrm{C}_{3} \mathrm{H}_{5} \mathrm{O}_{2} \mathrm{Cl}+\mathrm{C}_{2} \mathrm{H}_{2} \mathrm{~N}_{2} \mathrm{O}_{3} \mathrm{Cl}^{*}+\mathrm{C}_{2} \mathrm{H}_{2} \mathrm{~N}_{2} \mathrm{O}_{4} \mathrm{Cl}^{*}+\mathrm{C}_{5} \mathrm{H}_{5} \mathrm{NO}_{5} \mathrm{Cl}_{2}+\mathrm{CHO}_{2} \mathrm{Cl}$

Considering that ammonium perchlorate as energetic additive is used in a significant amount in solid propellants for large caliber rockets and cruise missiles, a huge volume of aggressive and reactive chlorinebased compounds and radicals are released into the atmosphere during a projectile flight. These aggressive and reactive compounds are also formed in detonation of mixtures of high explosives and halogen-based compounds. 


\section{Decomposition of vinyl chloride}

In the "Pančevo" refinery, a reservoir with vinyl chloride was deliberately targeted and destroyed. Vinyl chloride is very toxic and carcinogenic. It is used in the production of polyvinyl chloride - PVC. Beside carbon oxides and carbon formed by burning of vinyl chloride in the open air, toxic hydrochloric acid and extremely strong chlorine-based poison-phosgene are also formed as a result of vinyl chloride partial oxidation. (Savezno Ministarstvo za razvoj, nauku i životnu sredinu, 2000)

Vinyl chloride (chloroethane, chloroethylene), $\mathrm{CH} 2=\mathrm{CH}-\mathrm{Cl}$ is a colorless gas with ethereal odor, of molecular mass 62.50 , with the boiling point at $-13.9 \mathrm{C}$ and the melting point at $-160 \mathrm{C}$. The solubility of vinyl chloride in water is low and good in ethanol and ether. It is combustible and explosible. It is easily polymerized. The product of polymerization is plastic material polyvinyl chloride.

The combustion of vinyl chloride having leaked from the bombed and damaged tanks can be described by the following equation:

$$
2 \mathrm{CH}_{2}=\mathrm{CHCl} \stackrel{\mathrm{O}_{2}}{\rightarrow} \quad 2 \mathrm{CO}_{2}+2 \mathrm{CO}+\mathrm{H}_{2} \mathrm{O}+2 \mathrm{HCl}+\mathrm{H}_{2}
$$

When there is not enough oxygen, burning products react with each other in a gas phase and under the high temperature producing carbonyl chloride according to the following equation:

$$
\mathrm{CO}+2 \mathrm{HCl} \stackrel{\mathrm{hv}}{\rightarrow} \mathrm{COCl}_{2}+\mathrm{H}_{2}
$$

Carbonyl chloride, known as phosgene, belongs to chemical warfare gases of suffocating type. It releases odor of rotten fruit or hay.

The oxidation (burning) of vinyl chloride can go in two directions:

Complete combustion:

$$
2 \mathrm{CH}_{2}=\mathrm{CHCl}+11 \mathrm{O}_{2} \rightarrow 4 \mathrm{CO}_{2}+3 \mathrm{H}_{2} \mathrm{O}+\mathrm{Cl}_{2}
$$

Incomplete combustion:

hv

$$
\mathrm{CH}_{2}=\mathrm{CHCl} \rightarrow \mathrm{CO}+\mathrm{HCN}+\mathrm{HCl}+\mathrm{CO}_{2}+\mathrm{H}_{2} \mathrm{O}+\mathrm{H}_{2}+\mathrm{C}
$$


Both reactions are ongoing in parallel. Therefore, in combustion products of vinyl chloride, there are the products of complete and incomplete combustion, aggressive and toxic gases such as hydrogen cyanide $(\mathrm{HCN})$, chlorine $(\mathrm{Cl} 2)$, carbon mono oxide $(\mathrm{CO})$, carbon dioxide $(\mathrm{CO} 2)$, and hydrochloric acid $(\mathrm{HCl})$. The reactions between these combustion products when there is not enough oxygen and in the presence of light lead to phosgene oxime formation $(\mathrm{Cl} 2 \mathrm{CNOH})$.

$$
\mathrm{HCN}+\mathrm{Cl}_{2}+\mathrm{H}_{2} \mathrm{O} \rightarrow \mathrm{Cl}_{2} \mathrm{CNOH}+\mathrm{H}_{2}
$$

Phosgene oxime also belongs to chemical weapon agents. It is stronger than phosgene, which is a blistering agent, a choking agent, and an irritant (Minier \& Behrens, 1997).

In Pančevo, about 440 tons of vinyl chloride monomers (Savezno Ministarstvo za razvoj, nauku i životnu sredinu, 2000) were burned from the spherical reservoirs. Phosgene, a chemical warfare gas, is also a product of vinyl chloride monomers. The fire is shown in Figure 2.

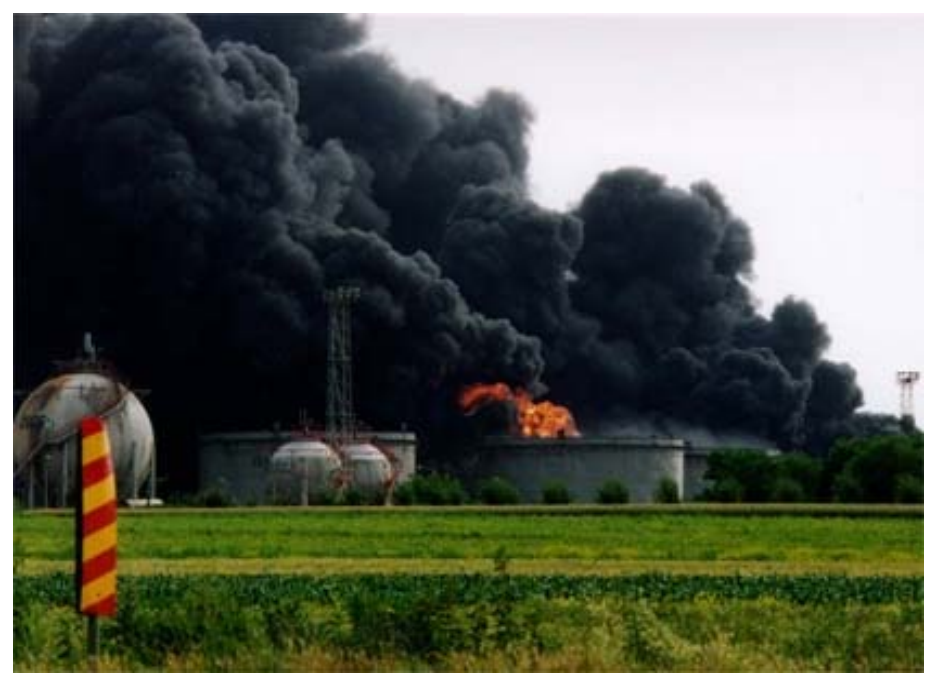

Figure 2 - Fire on the spherical reservoirs of vinyl chloride monomer in Pancevo Puc. 2 - Пожар в сфрерических резервуарах мономера винилхлорида в г.Панчево Слика 2 - Пожар на сфрерним резервоарима мономера винил хлорида у Панчеву

A thick, black toxic cloud, containing the products of vinyl chloride burning, hovered over the city of Pancevo for three days. Windy weather pushed this cloud over the entire mid-Europe up to the Scandinavian 
countries. Deliberately bombing of vinyl chloride tanks clearly confirms the intention of the aggressor to poison the human population of Serbia. Even though chemical warfare agents were not explicitly used, it can be said that putting tanks of vinyl chloride on fire can be considered as the use of chemical weapon agents.

\section{Conclusion}

Warheads of all kinds of projectiles used conventional explosives, mostly a mixture of trinitrotoluene (TNT) and hexogen. However, some other mixtures were used, like octogen and metriol trinitrate (MTN). To increase energy efficiency of these mixtures, different additives were used, like different plasticizers and oxygen rich inorganic ammonium salts. Ammonium perchlorate was mostly used. Ammonium nitrate was also used, but significantly less than perchlorate. Both compounds were applied as oxidizers rich in oxygen content. In order to increase energy efficiency of rocket propellants, fluorine-based compounds were mostly added. Therefore, besides their distruction effects, weapons used were releasing huge amounts of toxic and suffocating gases as products of combustion and detonation. The formed gaseous products of detonation contained carbon monoxide, carbon dioxide, nitrogen oxides, cyanocompounds, hydrogen, nitrogen, water in form of vapor, carbon in form of soot, and halogen radicals. These gaseous products of detonation in combination with the products of vinyl chloride fires had the effects of special chemical warfare carried out on the FR Yugoslavia in the year of 1999 .

\section{References}

Anđelković-Lukić, M. 2006. Ecological aspect of pyralen application. Vojnotehnički glasnik/Military Technical Courier, 54(3), pp.348-353 (in Serbian). Available at: https://doi.org/10.5937/vojtehg0603348A.

Anđelković-Lukić, M. 2009. Synthesis and physicochemical properties of the HNIW (CL-20) explosive. Vojnotehnički glasnik/Military Technical Courier, 57(2), pp.86-93 (in Serbian). Available at: https://doi.org/10.5937/vojtehg0902086A.

Anđelković-Lukić, M. 2000. New high-explosive explosive - polycyclic nitramine hexanitrohexaazaisovurcitan (HNIW, CL-20). Scientific Technical Review, 50(6).

Anđelković-Lukić, M. 2015a. Darovi milosrdnog anđela - Ekološko razmatranje rata NATO protiv SR Jugoslavije, 2. dopunjeno izdanje. Novi Sad: Balkanija (in Serbian). 
Anđelković-Lukić, M. 2015b. Chemical, Radiological and Environmental Impacts of NATO's War of Aggression against Yugoslavia. In: $19^{\text {th }}$ Internacional Scientific Eco-Conference, Novi Sad, Serbia, pp.39-50, 23-25 September.

Brousseau, P., \& Anderson C.J. 2002. Nanometric Aluminum in Explosives. Propellants, explosives, pyrotechnics, 27(5), pp.300-306. Available at: PREP300>3.0.CO;2-\%23. https://doi.org/10.1002/1521-4087(200211)27:5<300::AID-

Cai, W., Thakre, P., \& Yang, W. 2008. A Model of AP/HTPB Composite Propellant Combustion in Rocket-Motor Environments. Combustion Science and Technology. 180(12), pp.2143-2169. Available at: https://doi.org/10.1080/00102200802414915.

Dobratz, B.M. 1981. LLNL explosives handbook: properties of chemical explosives and explosives and explosive simulants. United States.

Minier, L.M.G., \& Behrens, R. 1997. Thermal decomposition mechanisms of bis(2-fluoro-2,2-dinitroethyl) formal (FEFO) and bis(2-fluoro-2,2-dinitroethyl) difluoroformal (DFF) from simultaneous thermogravimetric modulated beam mass spectrometry (STMBMS) measurements. Propellants, Explosives, Pyrotechnics, 22(1), pp.23-33. Available at: https://doi.org/10.1002/prep.19970220107.

-Savezno Ministarstvo za razvoj, nauku i životnu sredinu. 2000. Posledice NATO bombardovanja na životnu sredinu SR Jugoslavije - Izveštaj. Belgrade: Savezno Ministarstvo za razvoj, nauku i životnu sredinu (in Serbian).

Sundaram, D.S., Yang, V., \& Zarko, V.E. 2015. Combustion of nano aluminum particles (Review). Combustion, Explosion, and Shock Waves, 51(2), pp.173-196. Available at: https://doi.org/10.1134/S0010508215020045.

Weidong, C., Piyush, T., \& Vigor, Y. 2008. A model of AP/HTPB composite propellants combustion in rocket-motors environements. Combustion Science and Technology, 180(12), pp.2143-2169. Available at: https://doi.org/10.1080/00102200802414915.

ЭНЕРГЕТИЧЕСКИЕ АДДИТИВЫ, ДОБАВЛЕННЫЕ В ЗАРЯД КРЫЛАТЫХ РАКЕТ В ХОДЕ ВОЙНЫ ПРОТИВ СР ЮГОСЛАВИИ В 1999 ГОДУ

Мирьяна Н. Анджелкович-Лукич

Военно-технический институт, г. Белград, Республика Сербия

РУБРИКА ГРНТИ: 78.00.00 ВОЕННОЕ ДЕЛО;

78.25.12 Химическое, биологическое и зажигательное оружие. Средства защиты от оружия массового поражения

61.00.00 ХИМИЧЕСКАЯ ТЕХНОЛОГИЯ. ХИМИЧЕСКАЯ ПРОМЫШЛЕННОСТЬ;

61.01.94 Охрана окружающей среды

ВИД СТАТЬИ: оригинальная научная статья

ЯЗЫК СТАТЬИ: английский 
Резюме:

Вследствие использования боеприпасов, содержащих различные добавки для увеличения их энергии (соединений галогенов, металлов и восков) после взрыва которых высвобождались чрезвычайно токсичные газообразные вещества, которые в сочетании с бомбардируемыми объектами имели последствия особой химической войны.

Ключевые слова: боеприпасы, энергетические добавки, химическая война.

ЕНЕРГЕТСКИ АДИТИВИ ДОДАВАНИ ЕКСПЛОЗИВНИМ ПУЊЕЊИМА РАКЕТА У АГРЕСИЈИ НА СР ЈУГОСЛАВИЈУ 1999. ГОДИНЕ

Мирјана Н. Анђелковић-Лукић

Војнотехнички инститиут, Београд, Република Србија

ОБЛАСТ: хемијске технологије

ВРСТА ЧЛАНКА: оригинални научни рад

ЈЕЗИК ЧЛАНКА: енглески

Сажетак:

Убојним средствима додавани су различити додаци, као што су халогена једињења, метали и воскови, како би се повећала њихова енергија. После детонације убојних средстава ослобађали су се изузетно отровни гасовити продукти који су, у садејству са бомбардованим објектима, имали ефректе специјалног хемијског pama.

Кључне речи: убојна средства, енергетски додаци, хемијски рат.

Paper received on / Дата получения работы / Датум пријема чланка: 16.07.2019. Manuscript corrections submitted on / Дата получения исправленной версии работы / Датум достављања исправки рукописа: 01.08.2019.

Paper accepted for publishing on / Дата окончательного согласования работы / Датум коначног прихватања чланка за објављивање: 03.08.2019.

(c) 2019 The Author. Published by Vojnotehnički glasnik / Military Technical Courier (www.vtg.mod.gov.rs, втг.мо.упр.срб). This article is an open access article distributed under the terms and conditions of the Creative Commons Attribution license (http://creativecommons.org/licenses/by/3.0/rs/).

(c) 2019 Автор. Опубликовано в «Военно-технический вестник / Vojnotehnički glasnik / Military Technical Courier» (www.vtg.mod.gov.rs, втг.мо.упр.срб). Данная статья в открытом доступе и распространяется в соответствии с лицензией «Creative Commons» (http://creativecommons.org/licenses/by/3.0/rs/).

(c) 2019 Аутор. Објавио Војнотехнички гласник / Vojnotehnički glasnik / Military Technical Courier (www.vtg.mod.gov.rs, втг.мо.упр.срб). Ово је чланак отвореног приступа и дистрибуира се у складу са Creative Commons licencom (http://creativecommons.org/licenses/by/3.0/rs/). 